Jurnal ECOTIPE, Volume 6, No.2, Oktober 2019, Hal. 76 - 81

p-ISSN 2355-5068, e-ISSN 2622-4852

Akreditasi Kemenristekdikti (SINTA 4), SK. No.10/E/KPT/2019

DOI: 10.33019/ecotipe.v6i2.1019

\title{
Sistem Rekomendasi Pemilihan Laptop dengan Metode WASPAS
}

\author{
Kevin Arista Chandra ${ }^{1}$, Seng Hansun ${ }^{2}$ \\ Program Studi Informatika, Universitas Multimedia Nusantara ${ }^{12}$ \\ kevin.arista@student.umn.ac.id, hansun@umn.ac.id
}

\begin{abstract}
The invention of computers has revolutionalized our lives. As technological advancements continues to develop, computers had been shrinking in size as PC computers had developed into laptop computers. In order to collect information on an individual's behavior as well as preferences when it comes to their choice on laptops, a survey is conducted through questionnaire distribution. The survey result states that a majority of the respondents had claimed to have experienced difficulties in choosing a laptop that fits their personal preferences. Based on the aforementioned issues, a web based laptop recommender system is built as a solution. The aforementioned system was built using WASPAS Method which is a unique combination of the WSM method and WPM method. This method has been proven to be successfully implemented as a solution for MCDM (Multi Criteria Decision Making) problems. Programming languages used in the development of this system are HTML, PHP, and Javascript. User satisfaction test results indicated mostly positive responses from the respondents towards the system. The user satisfaction test results has the Cronbach's Alpha value of 0.83, stating that the test results are considered reliable. Also, validity test results confirms the validity of the obtained data.
\end{abstract}

Keywords : Laptop, MCDM, Recommendation System, WASPAS, Website

INTISARI

Komputer merupakan sebuah penemuan revolusioner yang memberikan banyak kontribusi bagi kehidupan manusia. Seiring berkembangnya teknologi, komputer berevolusi menuju ukuran yang lebih kecil, dari komputer desktop hingga komputer laptop. Untuk mengetahui perilaku dan preferensi masyarakat dalam memilih laptop, dilakukan survei sederhana menggunakan angket. Berdasarkan hasil survei, sebagian besar responden mengaku pernah mengalami kesulitan dalam memilih laptop yang sesuai dengan keinginan responden. Oleh karena itu, dibangun sebuah sistem rekomendasi laptop berbasis web. Pembangunan sistem ini dilakukan menggunakan metode WASPAS (Weighted Aggregated Sum Product Assesment). Metode WASPAS merupakan penggabungan dari metode WSM dan WPM. Metode ini dapat digunakan untuk menyelesaikan permasalahan MCDM (Multi Criteria Decision Making). Bahasa pemrograman yang digunakan untuk pembangunan website ini antara lain HTML, PHP, dan Javascript. Hasil uji kepuasan pengguna terhadap sistem yang dibangun menunjukkan bahwa mayoritas responden memberikan penilaian positif. Hasil perhitungan Cronbach's Alpha terhadap hasil uji kepuasan pengguna menghasilkan nilai sebesar 0,83 yang menunjukkan bahwa hasil uji kepuasan pengguna tergolong reliable. Selain itu, uji validitas menunjukkan bahwa data yang diperoleh tergolong valid.

Kata kunci: Laptop, MCDM, Sistem Rekomendasi, WASPAS, Website

\section{PENDAHULUAN}

Komputer merupakan sebuah penemuan revolusioner yang memberikan banyak kontribusi bagi kehidupan manusia. Seiring berkembangnya teknologi, komputer berevolusi menuju ukuran yang lebih kecil, dari komputer desktop hingga komputer laptop. Sejak tahun 1980, komputer portabel telah banyak diminati oleh masyarakat. Namun, setiap individu memiliki perilaku yang berbeda-beda dalam memilih laptop. Untuk mengetahui perilaku dan preferensi masyarakat dalam memilih laptop, dilakukan survei yang dilakukan menggunakan angket melalui sarana Google Forms.

Berdasarkan hasil survei yang disebarkan secara acak melalui sosial media, dari 31 orang responden, sebanyak $87,1 \%$ mengaku pernah merasa kesulitan dalam memilih laptop yang sesuai dengan keinginan pribadi responden. Oleh karena itu, dibangun sistem rekomendasi yang bertujuan untuk memberikan saran pilihan laptop berdasarkan kriteria yang diinginkan oleh 
Jurnal ECOTIPE, Volume 6, No.2, Oktober 2019, Hal. 76 - 81

p-ISSN 2355-5068, e-ISSN 2622-4852

Akreditasi Kemenristekdikti (SINTA 4), SK. No.10/E/KPT/2019

DOI: 10.33019/ecotipe.v6i2.1019

pengguna. Input dari sistem ini berupa kriteriakriteria laptop yang diinginkan user, beserta bobot penilaian untuk setiap kriteria. Lalu sistem akan mengeluarkan output berupa rekomendasi laptop yang sesuai dengan kriteria-kriteria tersebut.

Terdapat beberapa penelitian serupa yang membahas pemilihan laptop, seperti yang dilakukan oleh Setiawan dan Hansun [1], Hartanto dan Prasetiyowati [2], serta Kusnadi dan Kurniawan [3]. Berdasarkan penelitian yang dilakukan oleh Kusnadi dan Kurniawan [3] diperoleh saran untuk mengembangkan penelitian tersebut dengan menggunakan algoritma lain atau penggabungan algoritma untuk meningkatkan akurasi dan waktu proses atau respon sistem. Adapun simpulan dari penelitian serupa lainnya yang dilakukan oleh Fauzan [4] dengan judul Rancang Bangun Sistem Rekomendasi Pemilihan Smartphone Menggunakan Metode WASPAS Berbasis Web menunjukkan bahwa sistem yang dibangun memiliki koefisien Cronbach's Alpha sebesar 0,87 dan disimpulkan sistem tersebut reliable.

Metode WASPAS (Weighted Agregated Sum Product Assesment) merupakan salah satu metode MCDM (Multi Criteria Decision Making). Zavadskas dkk. [5] mengatakan bahwa diperkirakan metode WASPAS memiliki akurasi 1,3 kali lebih besar dibanding metode Weighted Product Model dan mencapai 1,6 kali lebih besar dibanding Weighted Sum Model. Oleh karena itu, sistem rekomendasi yang dibangun pada penelitian ini dilakukan dengan menggunakan metode WASPAS dengan basis Web.

Data yang digunakan dalam pembangunan sistem bersumber dari online shop www.bhinneka.com karena toko online ini telah dijadikan sumber data pada penelitian yang dilakukan oleh Kusnadi dan Kurniawan [3]. Sedangkan kriteria-kriteria yang digunakan didapat dari hasil penelitian tersebut yaitu harga, harddisk, processor, layar (monitor), Random Access Memory (RAM), berat, baterai dan garansi. Laptop yang dijadikan bahan pertimbangan memiliki sistem operasi Windows.

\section{LANDASAN TEORI}

\section{A. WASPAS}

Berikut merupakan penyelesaian perhitungan menggunakan metode WASPAS yang terdiri atas 4 (empat) langkah utama [5].

1. Normalisasi.

Langkah pertama, nilai kriteria diubah ke dalam bentuk yang telah dinormalisasi dengan persamaan (1) di bawah ini

$$
\bar{x}_{i j}=\frac{x_{i j}}{\max _{i} x_{i j}}
$$

\section{Keterangan:}

$x$ merupakan nilai kriteria sebelum normalisasi $\bar{x}$ merupakan nilai kriteria yang telah dinormalisasi $i$ menunjukkan alternatif ke-i

$j$ menunjukkan kriteria ke-j

Persamaan (1) di atas digunakan untuk kriteria benefit. Kriteria benefit berarti kriteria yang semakin diinginkan apabila nilai kriteria tersebut tinggi sedangkan kriteria cost berarti kriteria yang semakin diinginkan apabila nilai kriteria tersebut rendah. Normalisasi untuk kriteria cost dilakukan dengan persamaan (2) di bawah ini

$$
\bar{x}_{i j}=\frac{\min _{i} x_{i j}}{x_{i j}}
$$

2. Perhitungan dengan WSM menggunakan rumus pada persamaan (3) berikut

$$
W S M_{i}=\sum_{j=1}^{n} \bar{x}_{i j} \cdot w_{j}
$$

\section{Keterangan:}

$\bar{x}$ merupakan nilai kriteria yang telah dinormalisasi $w$ merupakan bobot kriteria

$i$ menunjukkan alternatif ke-i

$j$ menunjukkan kriteria ke-j

3. Perhitungan dengan WPM dengan rumus pada persamaan (4) berikut

$$
W P M_{i}=\prod_{j=1}^{n}\left(\bar{x}_{i j}\right)^{w_{j}}
$$


Jurnal ECOTIPE, Volume 6, No.2, Oktober 2019, Hal. 76 - 81

p-ISSN 2355-5068, e-ISSN 2622-4852

Akreditasi Kemenristekdikti (SINTA 4), SK. No.10/E/KPT/2019

DOI: 10.33019/ecotipe.v6i2.1019

4. Perhitungan nilai WASPAS dengan menggabungkan hasil perhitungan WSM dan WPM dengan menggunakan rumus pada persamaan (5) berikut

$$
Q_{i}=\lambda \cdot W S M_{i}+\left((1-\lambda) \cdot W P M_{i}\right.
$$

\section{Keterangan:}

$Q$ merupakan nilai WASPAS

$W_{S} M_{i}$ merupakan hasil perhitungan menggunakan WSM

$W P M_{i}$ merupakan hasil perhitungan menggunakan WPM

$\lambda$ merupakan bilangan real antara 0 hingga 1

\section{METODE PENELITIAN}

Metodologi penelitian yang digunakan pada penelitian ini adalah sebagai berikut:

1. Studi Literatur

Studi literatur dilakukan dengan membaca $e$ book, artikel, jurnal ilmiah, maupun referensi dari penelitian-penelitian terkait yang mendukung penelitian ini.

\section{Pengumpulan Data}

Pengumpulan data untuk penelitian ini dilakukan dengan survei angket melalui Google Forms menggunakan teknik Accidental Sampling. Penyebaran angket ini bertujuan untuk mengetahui perilaku masyarakat umum terhadap pemilihan laptop. Adapun data-data laptop yang diperlukan akan diambil dari toko online www.bhinneka.com 3. Perancangan dan Pembangunan Sistem

Perancangan sistem dilakukan dengan penyusunan diagram flowchart, DFD (Data Flow Diagram), dan ERD (Entity Relationship Diagram). Pembangunan sistem dilakukan menggunakan bahasa pemrograman PHP, Javascript, CSS, dan HTML.

\section{Pengujian dan Evaluasi}

Pada tahap ini akan dilakukan uji coba untuk melihat kesesuaian hasil yang didapat dari jalannya proses sistem yang telah dirancang dan meminimalisir kesalahan maupun kekurangan yang terdapat dalam perancangan sistem.

5. Penulisan dan Dokumentasi
Laporan penelitian disusun sebagai dokumentasi hasil pelaksanaan langkah-langkah di atas.

\section{HASIL PENELITIAN DAN PEMBAHASAN}

Adapun perangkat lunak (software) yang digunakan dalam pembangunan website ini adalah sebagai berikut:

- Sistem Operasi: Microsoft Windows 10 64-bit

- Text Editor: Sublime Text 3

- Desain diagram: Draw.io, PowerDesigner

- Web server software: Apache

- Web browser: Google Chrome

- PHP versi 7.2.10

Sementara perangkat keras (hardware) yang digunakan adalah sebagai berikut:

- Komputer: Laptop Lenovo Y700

- Processor: Intel®Core ${ }^{\mathrm{TM}}$ i7-6700HQ CPU @ $2.60 \mathrm{GHz}$

- Kapasitas RAM (Random Access Memory): $16 \mathrm{~GB}$

- GPU (Graphics Processing Unit): NVIDIA GeForce GTX 960M 12 GB

- HDD (Hard Disk Drive): 1 TB

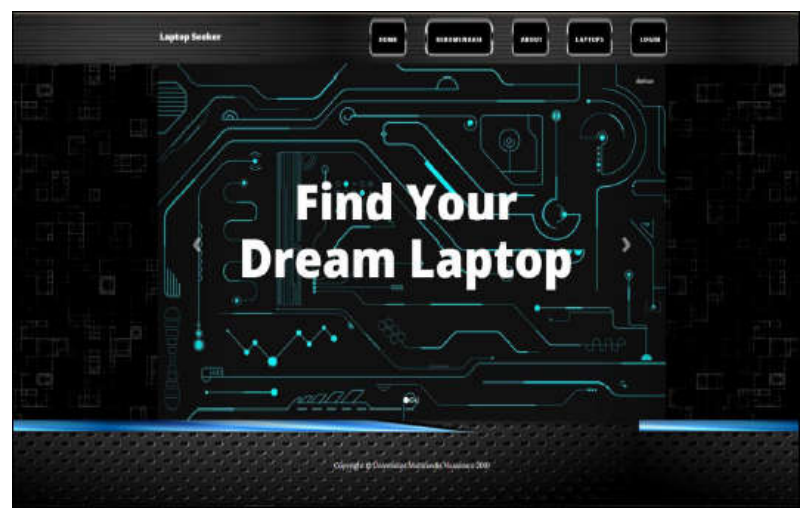

Gambar 1. Tampilan Halaman Home

Tampilan halaman Home atau halaman utama web dapat dilihat pada Gambar 1 di atas. Di bagian tengah halaman yang terletak diantara header dan footer terdapat carousel yang berisi gambar dan tulisan yang dapat diklik untuk pindah ke halaman yang sesuai dengan teks. Selain itu pengguna juga 
Jurnal ECOTIPE, Volume 6, No.2, Oktober 2019, Hal. 76 - 81

p-ISSN 2355-5068, e-ISSN 2622-4852

Akreditasi Kemenristekdikti (SINTA 4), SK. No.10/E/KPT/2019

DOI: 10.33019/ecotipe.v6i2.1019

dapat berpindah halaman menggunakan tomboltombol yang berada pada bagian header halaman.

Tampilan halaman Rekomendasi dapat dilihat pada Gambar 2 di bawah. Pada halaman Rekomendasi, pengguna disajikan pilihan filter yang berfungsi untuk menyaring data berdasarkan merek laptop. Adapun preferensi pengguna dapat diukur dengan menggunakan skala Likert dengan nilai minimum 1 atau Sangat Tidak Penting hingga 5 atau Sangat Penting. Adapun skala preferensi pengguna untuk masing-masing kriteria dibuat berdasarkan penelitian yang dilakukan oleh [2]. Pengguna diperlukan untuk mengisi semua skala Likert sebelum dapat menampilkan rekomendasi dengan menekan tombol Submit yang berada di bagian bawah halaman, sedangkan filter bersifat opsional.

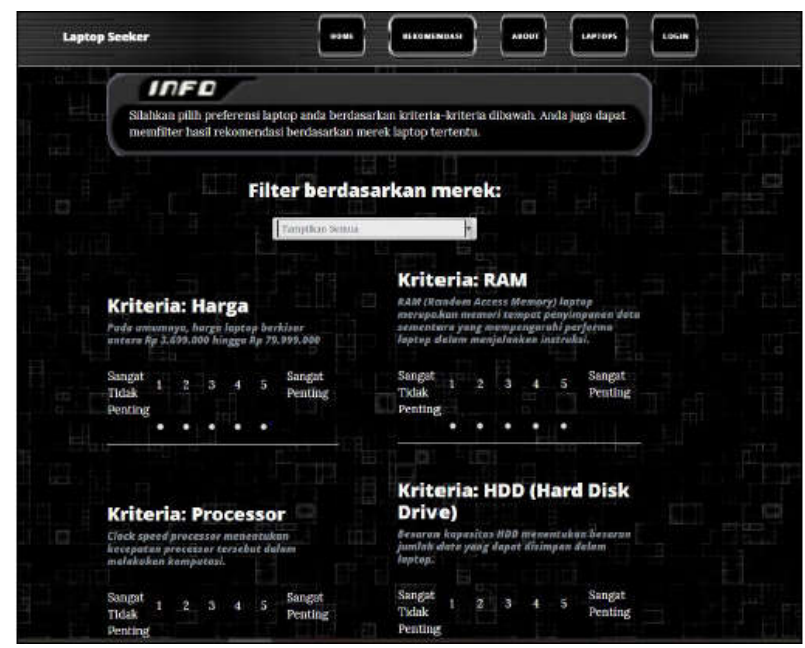

Gambar 2. Tampilan Halaman Rekomendasi

Setelah pengguna mengisi semua skala likert dan menekan tombol Submit, sistem akan menampilkan hasil rekomendasi kepada pengguna pada halaman Hasil. Tampilan halaman Hasil dapat dilihat pada Gambar 3 di bawah.

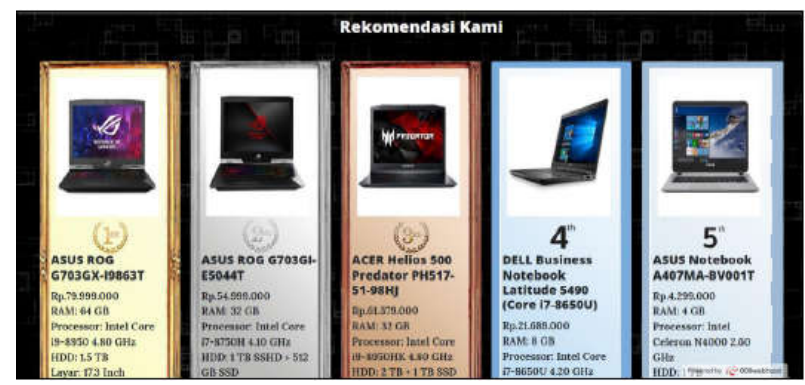

Gambar 3. Tampilan Halaman Hasil

Hasil rekomendasi sistem ditampilkan dalam bentuk card yang berjumlah lima buah dengan urutan peringkat dari sebelah kiri ke sebelah kanan. Di dalam masing-masing card, terdapat gambar serta spesifikasi laptop yang direkomendasikan kepada pengguna. Pada bagian bawah halaman terdapat tombol untuk kembali ke halaman Rekomendasi. Pengguna juga dapat berpindah ke halaman lainnya dengan menekan tombol pada header halaman.

Uji coba yang dilakukan pada penelitian ini terdiri dari 2 macam yaitu Uji Skenario dan Uji Kepuasan Pengguna. Uji Skenario dilakukan dengan melakukan perhitungan manual terhadap data sampel serta input yang ditentukan secara acak. Uji Skenario bertujuan untuk menguji ketepatan perhitungan pada metode WASPAS. Sedangkan Uji Kepuasan Pengguna dilakukan dengan mengumpulkan data dari responden yang telah menggunakan sistem yang bertujuan untuk mengukur kepuasan responden.

Uji kepuasan pengguna dilakukan dengan penyebaran angket kepada pengguna yang telah menggunakan sistem. Hill [6] menyatakan bahwa jumlah sampel yang direkomendasikan lebih besar dari 30 dan kurang dari 500.

Pada penyebaran angket ini, terdapat 35 responden yang telah menjawab lima buah pertanyaan. Pertanyaan-pertanyaan yang diajukan bertujuan untuk mengukur kepuasan pengguna berdasarkan landasan teori yang dinyatakan oleh Nelima, dkk [7] mengenai faktor-faktor yang mempengaruhi kepuasan pengguna.

Masing-masing pertanyaan diajukan dalam bentuk pernyataan dengan skala jawaban mulai 
Jurnal ECOTIPE, Volume 6, No.2, Oktober 2019, Hal. 76 - 81

p-ISSN 2355-5068, e-ISSN 2622-4852

Akreditasi Kemenristekdikti (SINTA 4), SK. No.10/E/KPT/2019

DOI: 10.33019/ecotipe.v6i2.1019

dari 1 (Sangat Tidak Setuju) hingga 5 (Sangat Setuju). Pertanyaan-pertanyaan yang diajukan kepada responden dapat dilihat pada Tabel 1 di bawah.

Tabel 1. Pertanyaan Angket

\begin{tabular}{|l|l|}
\hline No & Pertanyaan \\
\hline 1 & $\begin{array}{l}\text { Sistem yang dibangun mudah } \\
\text { digunakan }\end{array}$ \\
\hline 2 & $\begin{array}{l}\text { Tampilan informasi dan antarmuka } \\
\text { sistem sudah baik }\end{array}$ \\
\hline 3 & $\begin{array}{l}\text { Instruksi dalam penggunaan sistem } \\
\text { sudah jelas }\end{array}$ \\
\hline 4 & $\begin{array}{l}\text { Sistem telah menyediakan informasi } \\
\text { secara tepat dan akurat }\end{array}$ \\
\hline 5 & $\begin{array}{l}\text { Sistem yang dibangun tergolong } \\
\text { bermanfaat }\end{array}$ \\
\hline
\end{tabular}

Hasil penyebaran angket dapat dilihat pada Tabel 2 berikut ini.

Tabel 2. Hasil Penyebaran Angket

\begin{tabular}{|l|l|l|l|l|l|}
\hline Nilai & P1 & P2 & P3 & P4 & P5 \\
\hline 1 & 1 & 3 & 1 & 1 & 1 \\
& $(2,9 \%)$ & $(8,6 \%)$ & $(2,9 \%)$ & $(2,9 \%)$ & $(2,9 \%)$ \\
\hline 2 & 1 & 2 & 1 & 2 & 1 \\
& $(2,9 \%)$ & $(5,7 \%)$ & $(2,9 \%)$ & $(5,7 \%)$ & $(2,9 \%)$ \\
\hline 3 & 13 & 5 & 13 & 3 & 2 \\
& $(37,1 \%)$ & $(14,3 \%)$ & $(37,1 \%)$ & $(8,6 \%)$ & $(5,7 \%)$ \\
\hline 4 & 17 & 22 & 15 & 21 & 14 \\
& $(48,6 \%)$ & $(62,8 \%)$ & $(42,8 \%)$ & $(60 \%)$ & $(40 \%)$ \\
\hline 5 & 3 & 3 & 5 & 8 & 17 \\
& $(8,5 \%)$ & $(8,5 \%)$ & $(14,3 \%)$ & $(22,8 \%)$ & $(48,5 \%)$ \\
\hline
\end{tabular}

Berdasarkan tabel di atas dapat disimpulkan bahwa secara mayoritas responden menjawab Setuju untuk kelima pertanyaan yang diajukan. Persentase terbesar untuk jawaban Sangat Setuju terletak pada Pertanyaan 5, sedangkan persentase terbesar untuk jawaban Sangat Tidak Setuju terletak pada Pertanyaan 2. Dari hasil pengumpulan data, diperoleh hasil perhitungan koefisien reliabilitas Cronbach's Alpha sebesar 0,83 yang menunjukkan bahwa hasil uji coba kepuasan pengguna tergolong reliable.

Kemudian untuk menguji validitas data yang diperoleh dari hasil uji kepuasan pengguna, dilakukan uji validitas dengan melakukan perhitungan koefisien korelasi Pearson Product Moment antara total nilai dengan nilai yang diberikan reponden untuk masing-masing pertanyaan. Hasil uji validasi dapat dilihat pada Tabel 3 di bawah.

Tabel 3. Hasil Uji Validitas

\begin{tabular}{|l|l|l|}
\hline $\begin{array}{l}\text { No } \\
\text { Pertanyaan }\end{array}$ & $\begin{array}{l}\text { Nilai Koefisien } \\
\text { Korelasi }\end{array}$ & Keterangan \\
\hline 1 & 0,76 & Valid \\
\hline 2 & 0,74 & Valid \\
\hline 3 & 0,74 & Valid \\
\hline 4 & 0,89 & Valid \\
\hline 5 & 0,78 & Valid \\
\hline
\end{tabular}

Berdasarkan pernyataan dalam penelitian yang dilakukan oleh Gumulya dan Widiastuti [8], nilai-nilai yang diperoleh untuk pertanyaan yang memiliki koefisien korelasi lebih besar atau sama dengan 0,3 dinyatakan valid.

\section{KESIMPULAN}

Berdasarkan hasil penelitian yang dilakukan, disimpulkan bahwa sistem rekomendasi laptop dengan metode WASPAS berbasis web telah berhasil dibangun. Dari hasil uji kepuasan pengguna yang dilakukan melalui penyebaran angket, mayoritas responden menjawab Setuju untuk kelima pertanyaan yang merujuk kepada faktor-faktor yang mempengaruhi kepuasan pengguna [7]. Dari hasil penyebaran angket, didapat nilai koefisien reliabilitas Cronbach's Alpha sebesar 0,83 yang menunjukkan bahwa sistem hasil uji coba kepuasan pengguna tergolong reliabel. Selain itu, uji validitas menunjukkan bahwa data yang diperoleh tergolong valid.

Untuk penelitian selanjutnya, disarankan untuk ditambahkan fitur insert data yang memungkinkan sistem untuk mengambil data secara otomatis dari sumber data, sehingga backend website tidak diperlukan. Disarankan pula 
Jurnal ECOTIPE, Volume 6, No.2, Oktober 2019, Hal. 76 - 81

p-ISSN 2355-5068, e-ISSN 2622-4852.

Akreditasi Kemenristekdikti (SINTA 4), SK. No.10/E/KPT/2019

DOI: 10.33019/ecotipe. v6i2.1019

untuk menyelidiki lebih lanjut mengenai nilai lambda yang lebih optimal untuk sistem rekomendasi serupa yang menggunakan metode WASPAS.

\section{DAFTAR PUSTAKA}

[1] Setiawan, H. dan Hansun, S. (2014). Rancang Bangun Aplikasi Rekomendasi Pembelian Laptop dengan Metode Fuzzy Database Model Tahani Berbasis Web. Komputa Jurnal Ilmiah Komputer dan Informatika, 3(2), 86-95.

[2] Hartanto, T. dan Prasetiyowati, M.I. (2012). Sistem Pendukung Keputusan Pemilihan Laptop Berbasis Web dengan Metode Analytical Hierarchy Process (Studi Kasus: SAMCO COMPUTER). ULTIMATICS, 4(2), 7-15.

[3] Kusnadi, A. dan Kurniawan, E. (2017). Implementation of Topsis Method in Web Based System Recommendations for Students Laptop Selection (Case Study: Bhinneka.com). IJNMT, 4(1), 42-45.

[4] Fauzan, M.A. (2017). Rancang Bangun Sistem Rekomendasi Pemilihan Smartphone dengan Metode WASPAS Berbasis Web. Skripsi. Universitas Multimedia Nusantara, Tangerang.

[5] Zavadskas, E.K., Turskis, Z., Antucheviciene, J., dan Zakarevicius, Z. (2012). Optimization of Weighted Aggregated Sum Product Assessment. ELEKTRONIKA IR ELEKTROTECHNIKA, 122(6), 3-6.

[6] Hill, R. (1998). WHAT SAMPLE SIZE is 'ENOUGH' in INTERNET SURVEY RESEARCH? Interpers. Comput. Technol. J., 6(3-4), 1-10.

[7] Nelima, P., Mbugua, S.M., dan Kilwake, J. (2016). Factors Affecting Information Systems User Satisfaction in Kenyan Universities. J. Emerg. Trends Comput. Inf. Sci., 7(2), 116-127.

[8] Gumulya, J. dan Widiastuti, M. (2013). Pengaruh Konsep Diri Terhadap Perilaku
Konsumtif Mahasiswa Universitas Esa Unggul. Jurnal Psikologi, 11(1), 50-65. 